JARES, Vol. 3 No. 2 September, 2018; p-ISSN: 2502-826X; e-ISSN: 2503-1163

Copyrights@Balitar Islamic University, Blitar, Indonesia;

Http://jares.unisbablitar.ejournal.web.id

\title{
THE MODEL OF PUBLIC INFORMATION OPENNESS
}

"Interactive Broadcast of Memorandum of Understanding (MoU) between

Blitar Government and Village Government in the Supervision of the

Village Fund Allocation's Implementation"

\author{
${ }^{1}$ Yefi Dyan Nofa Harumike, \\ ${ }^{1}$ Universitas Islam Balitar, Majapahit Street No. 4a, Sanan Wetan, Blitar, East Java, 66137 \\ E-mail: yeanfake@gmail.com, \\ ${ }^{2}$ Anam Miftakhul Huda \\ ${ }^{2}$ Universitas Islam Balitar, Majapahit Street No. 4a, Sanan Wetan, Blitar, East Java, 66137. \\ E-mail: a6.asix6@yahoo.co.id,
}

\begin{abstract}
This research aims to provide information to the society related to the information openness and transparency of Blitar Government and Village Government in the implementation of Memorandum of Understanding (MoU) of Village Fund Allocation. Several issues stated in MoU include safety and orderliness, action, investigation, apparatus source, society protection, and connection. Other issues include prevention, supervision, and security of village fund. This research employed qualitative method with descriptive approach. The data were obtained from the document of interactive dialog broadcast named "Hallo Bupati" aired by Local Public Broadcast Department (LPPM) radio, Persada FM, Blitar, edition of Monday, January 23, 2018. The informant of this interactive dialog program was the Regent of Blitar. Data analysis was performed by transcribing the broadcast document, organizing and analyzing data, and interpreting the findings. The result showed that all the village governments getting Village Fund Allocation in Blitar have madeMemorandum of Understanding (MoU) with the Regent and the Chief Police Officer of the Regency Then, it was followed by supervision and evaluation towards the expenditure of the fund in village level.
\end{abstract}

Keywords: Interactive Model, (MoU), Village Fund Allocation (ADD), information and transparency

\section{INTRODUCTION}

Indonesia is a democratic country. The democracy means from people, by people, and for people. The development of government in Indonesia once experienced reformation era, which changed some systems both in central and local government. Some of the systems currently being implemented in regional level are fiscal decentralization and regional autonomy. Decentralization and regional autonomy are the government's effort to provide full access to each Regency and City to manage plans and implementation in the juridical region. 
JARES, Vol. 3 No. 2 September, 2018; p-ISSN: 2502-826X; e-ISSN: 2503-1163

Copyrights@Balitar Islamic University, Blitar, Indonesia;

Http://jares.unisbablitar.ejournal.web.id

The decision related to the regional autonomy is stated in the Law no. 23 Year 2014, related to the Regional Government: it is the autonomous region that has the right and obligation to rule and take care of its own government and society in the system of Unitary State of the Republic of Indonesia. The existence of the law about village is the reinforcement of the village status as the society government, in addition to being the foundation to develop and empower village people. Due to the rationale, the government has established a policy, that is, Village Fund Allocation as the representation of fiscal decentralization to the independent village.

Village Fund is sourced from the State Budget allocated to each village either in a Regency or City through the Regional Budget of Regency and City. Village Fund is used to fund all the government's activities, development, and all the activities related to the enhancement of the society's welfare. One of the Regencies in East Java that also receives Village Fund Allocation is Blitar Regency.

In the realization of the Village Fund's disbursement, MoU is created between the Regency Government and Village Government. MoU is started with an agreement approved by the Village Goverment, the Regent, and the Chief Police Officer. In addition to the society's welfare, MoU is also made to anticipate the misuse of Village Fund. Some issues are stated in MoU including safety and orderliness, action, investigation, apparatus source, society protection, and connection. Besides, it is also stated the issue of prevention, supervision, and security of Village Fund.

Geographically, Blitar is located at $11125^{\prime}-112$ 20' West Longitude and 7 57-8 9'51 South Latitude, precisely at the southwest of the Capital City of East Java Surabaya with the approximate distance of $160 \mathrm{Km}$ (http://www.blitarkab.go.id/2012/06/06/gambaran-umum-2/). As one of the regencies receiving Village Fund since 2018, Blitar has made a major progress in economic field at the level of village. This is proved by the existence of village markets and micro business in Blitar.

The research problems of this research are as follows: How is the model of information openness related to the Memorandum of Understanding (MoU) between Blitar Regency Government and Village Government in the supervision of the Village Fund's implementation? 
JARES, Vol. 3 No. 2 September, 2018; p-ISSN: 2502-826X; e-ISSN: 2503-1163

Copyrights@Balitar Islamic University, Blitar, Indonesia;

Http://jares.unisbablitar.ejournal.web.id

\section{RESEARCH METHOD}

This research employed qualitative method using descriptive approach. Qualitative research method is a descriptive research that tends to use analysis. Process and meaning (subject perspective) is the central point in qualitative research. Theoretical basis is utilized as the guide to make the focus of the research in line withthe facts in the field.

Kriyantono says, "Qualitative research aims to explain phenomena deeply through in-depth data collection." Qualitative research stresses on the deepness of the collected data. The deeper and more detail the collected data are, the better the quality of the research is. Different from quantitative research, objects in qualitative research are generally limited. In this research, the researchers took part in the conditions being studied. The result of this research needs deep analysis from the researchers. Besides, the results are subjective which means that they are not generalizable. Generally, qualitative research is conducted by using interview and observation. Through these methods, the researchers would analyze the obtained data in detail. The researchers were unable to study the social condition of the object being observed since all the reality is a unity happening naturally. Results of qualitative research also create new theory or concept if they are against the previous theory and concepts (Kriyantono: 2006).

This research employed accurate and valid data; therefore, the techniques to collect the data were interview and documentation. Interview was conducted with the relevant informants. Interview was utilized to obtain all the necessary information in depth and detail. Interviewing also enabled the researchers to directly or indirectly interact with the informants. Meanwhile, documentation was in the form of text message and phone call delivered by the people to the informants.

\section{RESULT AND DISCUSSION}

Public Broadcast Department Persada FM Radio is a Blitar Goverment Radio airing on the frequency of FM 93.00 MHz. Persada FM does the broadcast in a studio located at the Hall of Blitar Regency, St. Semeru 40, Blitar - East Java. Persada FM, Information Media and Family Entertainment. The daily broadcast begins at 8.00 a.m and ends at 23:59 a.m. Persada FM Music and Information Radio. Address: Street. 
JARES, Vol. 3 No. 2 September, 2018; p-ISSN: 2502-826X; e-ISSN: 2503-1163

Copyrights@Balitar Islamic University, Blitar, Indonesia;

Http://jares.unisbablitar.ejournal.web.id

Semeru 40 Blitar SMS/wa: 081.233.00.233 On Air : 0342803488 Email :

persadafmblitar@yahoo.com, Website : www.persadafmblitar.com

\section{OPENNESS}

In this discussion, openness relates to any information sourced from the policies or rules established by the government. Policy is a condition when everything is understandable, accessible, and valid. People are easier in accessing information in the digital era. With all the advancement of information and communication technology, the government must be able to provide service to the society, related to the information openness itself.

Openness also has a great impact on the society by which it facilitates people to do state activities. With openness, people can be faster in accessing information. The government, in line with the advancement of era, must be active and provide excellent service to the society related to the information system in every field. In addition to providing comprehensive information, the government also must be able to control and filter any shared information to avoid misunderstanding.

Openness will greatly influence state activities. Viewed from cultural aspect, for example, outside cultures can be easily accessed through digitalization system. Viewed from governmental aspect, people is easy to find information, know the newest issues, policies, government systems, etc. of either their country or other countries. If the government is unable to control and filter any information, a country's stability will be distracted.

The government must always be transparent in doing their duties and responsibilities. Transparency means openness of the government in providing information related to the public resource management to those who need information (Mardiasmo, 2010:30).

Village Fund has been allocated for the last three years: 2015, 2016, and 2017. The fund has been increased in those three years. It appears that the villages have made progress due to allocation of the fund. Here, the Village Head's responsibility is crucial. The improvement of the villages must be reported to the higher leaders such as the Regent, Governor, and the Ministry of Village Development. The Regent of Blitar said. 
JARES, Vol. 3 No. 2 September, 2018; p-ISSN: 2502-826X; e-ISSN: 2503-1163

Copyrights@Balitar Islamic University, Blitar, Indonesia;

Http://jares.unisbablitar.ejournal.web.id

\section{INFORMATION}

In communication, the communicator and communicant deliver message and exchange information each other. Information is the analyzed data that becomes the foundation to take correct decisions (Bodnar, 2000: 1). Information comes from the existing data. According to The Liang Gie, data is things, events, or realities that contain knowledge to make it as a basis in arranging information, making conclusion, and applying decision.

Distribution of information is a process in which information is delivered to the people based on their needs, and it must be adjusted to time. In the delivery of information, the media used also must be appropriate; this can influence the level of acceptance of the information. With the advancement of information technology, space and time are no longer obstacles in delivering and accessing information. Any necessary information can be easily obtained.

In Indonesia, information stream related to the public interest is stated on Law no. 14 Year 2008. The law consisting of 64 sections mainly assign every Public Agency to open access to each public information requester to get public information, except some particular information. Although the law has been established, not all the information can be shared. Some information are kept in secret since if those information are published, they can distract the stability of a country.

\section{MOU (MEMORANDUM OF UNDERSTANDING)}

MoU (Memorandum of Understanding) is a legal document that explainsagreement between two parties. MoU often becomes the foundation of cooperation between two parties. In Blacks Law dictionary, memorandum is a summary of written statement that explains requirement of an agreement or transaction. Meanwhile, understanding is a statement of indirect agreement upon other agreements; or a legal contract signing upon an informal material or low constraint requirement, unless the statement is accompanied with or the result of agreement among some parties expected by the two parties to bind.

Officially, the village fund must be implemented properly, and avoided from any obstacles. Other parties also must have responsibility and right to control. Whether they are society figures, media, Non-Governmental Organization, or police. Of course, they have right to control. One thing that we must be proud of 
JARES, Vol. 3 No. 2 September, 2018; p-ISSN: 2502-826X; e-ISSN: 2503-1163

Copyrights@Balitar Islamic University, Blitar, Indonesia;

Http://jares.unisbablitar.ejournal.web.id

is that there is a MoU from the Minister of Home Affairs, the Minister of Acceleration Development Backward Regions, and the Regional Chief Police Officer. It shows the seriousness of the National Chief Police Officer to develop the backward village. Hopefully there is no problem.

\section{GOVERNMENT}

Government has a broad definition; it is an organization that has the right to make policies. The established policies are in the form of law implementation and laws of a particular area. Those laws are legal in their authoritative region. Government has narrow and broad definitions. The narrow definition of the government is that it is an instrument or complementary tool; the government is only an executive department. The broad definition of the government is that it covers all the state apparatus, starting from departments that implement all the policies and laws established by the government.

The government of one country and another country is different; they have different policies, rules, and laws. The system of government of each country is also different. The authoritative area and the border of a country also influence the system of government of that country. Information system and communication in accessing public information is different, too. Indonesia is a democratic country. Democracy is a form of government that provide opportunities for the people to take part in the decision making process and give their votes freely and equally. Therefore, anything is from the people, for the people, ad by the people.

As said by the Regent of Blitar,

"This $\mathrm{MoU}$ is wide-ranging covering the issue of safety and orderliness, action, investigation, apparatus source, protection, and connection. Other issues include prevention, supervision, and security of village fund. We must also provide training to the high performing students in the selection of the Indonesian National Police Officer. The candidates of the National Police as well as other fields we need. This MoU contains agreement with police"

\section{Radio as a Transparent Medium in Village Fund Allocation}

Based on the Government Regulation Number 43 Year 2014, Village Fund Allocation is sourced from the State Budget addressed to the villages through the Regional Budget to fund the government impementation, development, supervision, and empowerment of the society. The goals of Village Fund Allocation in Banyuwangi Regency are: (1) Helping the operational of the village government implementation, (2) 
JARES, Vol. 3 No. 2 September, 2018; p-ISSN: 2502-826X; e-ISSN: 2503-1163

Copyrights@Balitar Islamic University, Blitar, Indonesia;

Http://jares.unisbablitar.ejournal.web.id

Overcoming poverty and decreasing social inequality, (3) Enhancing the planning and budgeting of the village development and society's empowerment, (4) Developing village infrastructure, (5) Improving the implementation of religious value and culture to enhance the social improvement, (6) Improving tranquility and orderliness, (7) Improving service to the villagers to develop social activity and economy, (8) Boosting the improvement of self-supporting and community self-help, (9) Increasing the village and villagers' income through Village Business Entity, (10) Enhancing the role and function of the village departments, and (11) facilitating he program of national government, province government, and regency government (Journal of Ilmu dan Riset Akuntansi : Volume 5, Number 11, November 2016).

\section{Framework}

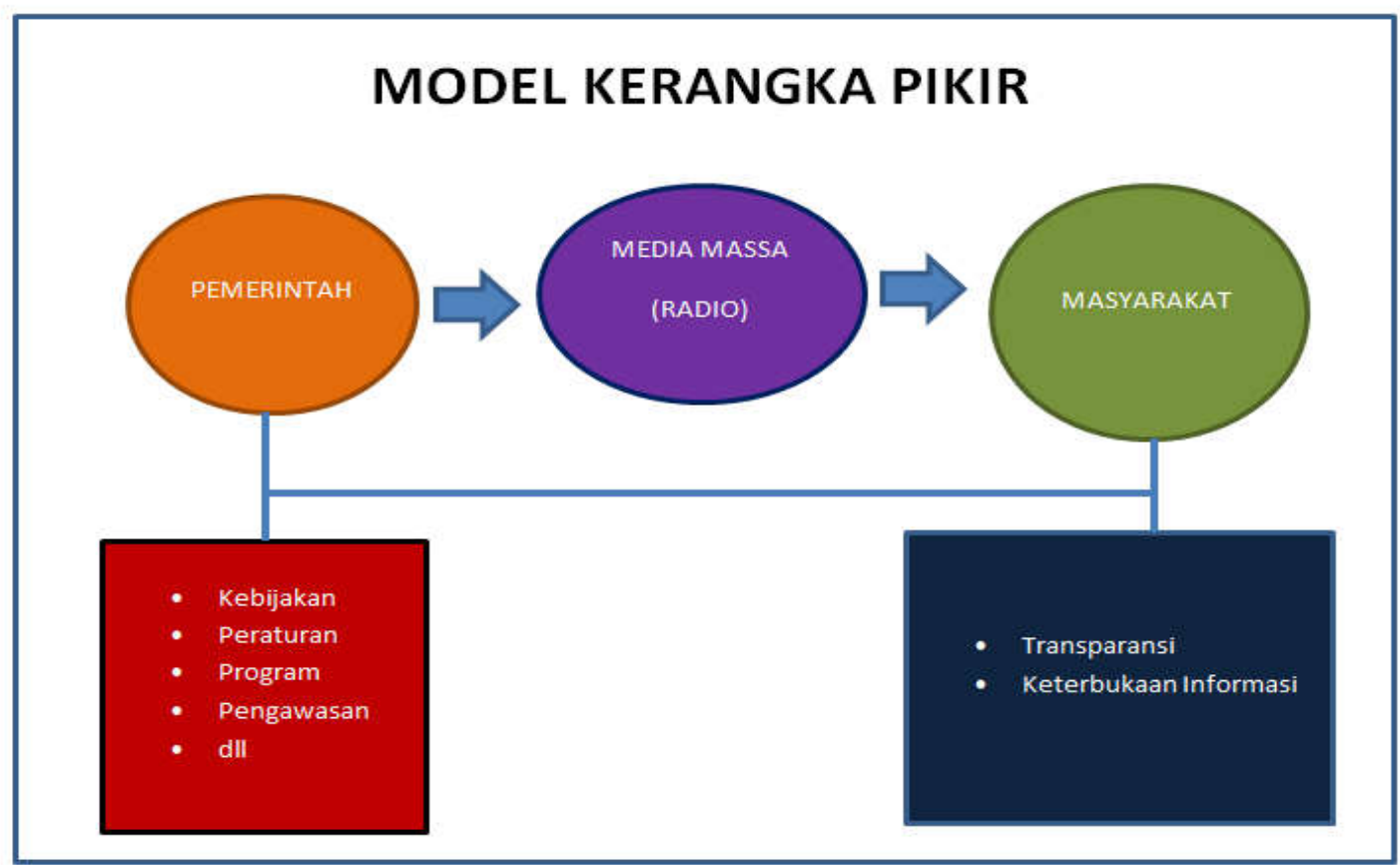

In this research, the government utilized radio as a medium to provide information related to the policy, regulation, program, monitoring, etc. to the society. The goal of the radio broadcast is to provide people with the update information related to the government, aiming at the society's welfare.

The use of radio is a form of transparency done by the government. As one of the excellent service in the way of improving the people's trust to the government, radio must be neutral and able to be one of the social controls. 
JARES, Vol. 3 No. 2 September, 2018; p-ISSN: 2502-826X; e-ISSN: 2503-1163

Copyrights@Balitar Islamic University, Blitar, Indonesia;

Http://jares.unisbablitar.ejournal.web.id

\section{People's Interactive Responses}

There are some received messages; one of those is from number 6155. "Does cyber extortion belong to MoU between the government and police officer?" Meanwhile, from number 5845, "Yesterday, a civil servant was caught by cyber extortion team, how is his condition now?" Then, from number 4094, "Sir, if there is a civil servant caught, what actions, and sanctions for them?" From number 5845, he said that village fund becomes authority of the village government and then, how is the government's responsibility? Afterward, from number 4094, "Why Regional Police Officer is involved in the supervision of the village fund?"

\section{The Responses of the Regent of Blitar}

Regarding cyber extortion, it is a policy which is started to be implemented from the central government. From the President's instruction, then it is followed by the levels below the President. Starting from the central government; Minister of Home Affairs, Governor, Regional Chief Police Officer, and so on. As a consequence, cyber extortion is formed to discover the people's complaints regarding the poor service that causes extortion. Therefore, cyber extortion is crucial to eliminate extortion.

\section{Conclusion}

The existence of radio notably interactive broadcast about the Memorandum of Understanding (MOU) between Blitar government and village government is crucial in the supervision of Village Fund Allocation. Radio plays role as a social control. The $\mathrm{MoU}$ is implemented to make the development effective Therefore, with the MoU, the supervision can focus on the preventive actions. If there is a wrong implementation, it will be warned directly, and it is effective. 
JARES, Vol. 3 No. 2 September, 2018; p-ISSN: 2502-826X; e-ISSN: 2503-1163

Copyrights@Balitar Islamic University, Blitar, Indonesia;

Http://jares.unisbablitar.ejournal.web.id

\section{References}

Bodnar, George H. William S. Hoopwood, 2000, Sistem Informasi Akutansi, Translated by Amir Abadi jusuf and R. M Tambunan, Sixth Edition, Book one, Salemba Empat, Jakarta.

Mardiasmo,. 2002. Otonomi dan Manajemen Keuangan Daerah. Yogyakarta: Andi

Mulyadi. 2009. Auditing. 6th edition. Book 1 Salemba Empat. Jakarta.

Kriyantono, Rachmat,. 2006. Teknik Praktis Riset Komunikasi. Jakarta: Prenada 